DOI: https://doi.org/10.36477/tourismhospcee-1-7

УДК 338.488 .2

Мельник I. М.

доктор економічних наук, доцент, професор кафедри туризму та готельно-ресторанної справи

Львівського торговельно-економічного університету ORCID: https://orcid.org/0000-0002-3132-6500

Melnyk Iryna

Lviv University of Trade and Economics

\title{
СТАН, ПРОБЛЕМИ ТА ПЕРСПЕКТИВИ РОЗВИТКУ САНАТОРНО-КУРОРТНИХ ТА ОЗДОРОВЧИХ ЗАСОБІВ РОЗМІЩЕННЯ В УКРАЇНІ
}

\author{
CURRENT CONDITION, PROBLEMS AND PROSPECTS \\ OF DEVELOPMENT OF SANATORIUM AND HEALTH FACILITIES \\ IN UKRAINE
}

\begin{abstract}
Проаналізовано сучасний стан розвитку мережі санаторно-курортних закладів та спеціалізованих засобів розміщення як основних об'єктів санаторно-курортного комплексу України. Встановлено загальну тенденцію до їх скорочення, щио не відповідає зростаючим потребам населення у підтримці здорового способу життя. Географія санаторно-курортних закладів України значною мірою відповідає територіальнокомпонентній структурі рекреаційних ресурсів і рекреаційних потреб. Виявлено основні причини негативних тенденції розвитку, зокрема зміна форми господарювання санаторно-курортних закладів та зменшення рівня платоспроможності значної частки населення. Обтрунтовано невідповідність даних офіційної статистики реальному стану розвитку санаторно-курортних об'єктів та неоднозначне відображення загального переліку останніх. Визначено основні напрями реалізації ключових заходів щзодо активізації розвитку закладів санаторно-курортного та оздоровчого профілю.
\end{abstract}

Ключові слова: санаторно-курортна галузь, лікувально-оздоровчий туризм, санаторно-курортний заклад, спеціалізований засіб розміщення, оздоровчий заклад, санаторій.

Проанализировано современное состояние развития сети санаторно-курортных учреждений и специализированных средств размещения как основных объектов санаторно-курортного комплекса Украины. Установлено общую тенденцию к их сокращению, что не соответствует растущим потребностям населения в поддержании здорового образа жизни. География санаторно-курортных учреждений Украинь в значительной степени соответствует территориально-компонентной структуре рекреационньх ресурсов и рекреационных потребностей. Выявлены основные причины негативных тенденций развития, в частности изменение формы хозяйствования санаторно-курортных учреждений и снижение уровня платежеспособности значительной части населения. Обоснованно несоответствие данных официальной статистики реальному положению развития санаторно-курортньх объектов и неоднозначное отражение общего перечня последних. Определень основные направления реализачии ключевых мер по активизации развития учреждений санаторно-курортного и оздоровительного профиля.

Ключевые слова: санаторно-курортная отрасль, лечебно-оздоровительный туризм, санаторно-курортное учреждение, специализированное средство размещения, оздоровительное учреждение, санаторий.

Modern challenges and pressures force us to treat health and wellbeing as our greatest commodities. And due to the high demand for this product, health tourism is becoming increasingly important. The structure of the domestic sanatorium-resort base today is represented by a variety of specialized accommodation facilities that offer a wide range of medical and recreational services. The objects of the sanatorium-resort base are represented in two specializations: medicine along with health care and tourist activity. This determines the semantic ambiguity of these enterprises and their structure. The problem of proper audit of the objects for their real assessment due to the ambiguity of statistical information is also determined. During the period of Ukraine's independence, the powerful sanatorium and resort base, which existed in Soviet times, was practically destroyed, which isn't improved in the conditions of the pandemic restrictions. This is confirmed by the data of the National Tourist Organization of Ukraine, as the volume of domestic tourists decreased by almost 18\% in the period of 2011-2019. Poor quality of the official statistics significantly complicates the objective analysis of trends in the development of the sanatoriumresort base of Ukraine. Despite claiming that recreation centers and sanatoriums occupy the largest share of the industry, official statistics fail to mention the huge segment of collective and individual accommodation that offer a variety of relevant health, recreation and leisure services, using natural and climatic conditions and recreational 
resources. In general, specialized accommodation facilities are unevenly located on the territory of Ukraine, which is logical due to the distribution of appropriate natural and climatic resources. Fostering the development of the industry requires modernization in several financial and managerial areas. Systems of incentive should be created to encourage investment in modernization and construction of facilities offering an affordable health product in compliance with state's treatment and rehabilitation standards.

Keywords: sanatorium-resort branch, medical-health tourism, sanatorium-resort establishment, specialized accommodation, health facility, sanatorium.

Постановка проблеми. Невід'ємною частиною та одним із найприбутковіших секторів індустрії туризму є лікувально-оздоровчий і курортнорекреаційний туризм, який охоплює всі верстви, вікові, соціальні, етнічні групи населення. Практика свідчить, що для великої кількості жителів планети закономірно хоча б один раз у рік відпочивати у різного роду курортно-рекреаційних засобах розміщення. В Україні цьому сприяє виграшне поєднуються багатих природних ресурсів, що можуть використовуватися для збереження і покращення здоров'я населення, подовження тривалості життя, зокрема: сприятливий клімат лісів, гірських та приморських місцевостей; унікальний мікроклімат соляних шахт; багатий спектр природних мінеральних вод; лікувальні грязі, озокерит тощо. Нині центрами санаторно-курортного та оздоровчого туризму є гірські та передгірні райони Закарпаття, Івано-Франківщини, Львівщини, Чорноморське узбережжя Миколаївської, Херсонської та Одеської областей, які мають певну інфраструктуру для розміщення туристів.

У сучасних умовах у санаторно-курортній справі України простежуються структурні зміни, пов'язані, в першу чергу, з організаційно-управлінськими аспектами, а саме: збільшується кількість приватних закладів, збільшується кількість пропозиції санаторно-курортного відпочинку тощо [1]. Разом з тим, невпинне зростання попиту i запитів туристів, загострення конкуренції між самими курортами веде до активізації темпів освоєння рекреаційних ресурсів, постійного пошуку інновацій у сфері освоєння рекреаційного продукту. Тому актуальним $є$ вивчення особливостей функціонування санаторно-курортної та оздоровчої бази України в умовах сьогодення, а також обгрунтування заходів, спрямованих на удосконалення ії структури.

Аналіз останніх досліджень і публікацій. Проблемі розвитку санаторно-курортного комплексу присвячено багато праць вчених-економістів і практиків. Так, вивченням теорії та практики організації санаторно-курортної справи займалися Г. Казачковська, О. Любіцева, Т. Ткаченко та інших. Тенденції розвитку лікувально-оздоровчого туризму та санаторно-курортної бази досліджували такі вчені: М. Ковач [2], І. Литовченко [3], Ю. Мигалина [4], С. Нездоймінов [5]. Оцінці стану розвитку туристичних підприємств та у тому числі санаторно-курортних закладів, присвя- чені роботи Ю. Забалдіної [6], А. Охріменко [7], I. Федорова [8]. Аналіз публікацій цих та інших авторів свідчить, що деякі з них торкалися окремих аспектів діяльності санаторно-курортногокомплексу, або досліджували стан та перспективи його розвитку в окремих регіонах України. Крім того, наявний статистичний аналіз тенденцій розвитку санаторно-курортних закладів дещо застарів, потребує певного оновлення та коригування.

Виділення невирішених раніше частин загальної проблеми. Отже, 3 вищезазначеного видно, що залишається недостатньо вивченою проблема грунтовного аналізу стану та тенденцій розвитку санаторно-курортного комплексу України, що зумовлює актуальність обраної теми.

Постановка завдання. Метою статті $\epsilon$ вивчення сучасного стану та тенденцій розвитку санаторно-курортного комплексу України, вирішення якої потребує систематизації наявної статистичної інформації щодо діяльності санаторнокурортних закладів та визначення основних проблем і шляхів подальшого розвитку вітчизняного санаторно-курортного комплексу.

Виклад основного матеріалу дослідження. Сьогодення вимагає від сучасної людини активної праці та підтримки високої фізичної активності, що спонукає іii до оцінки свого здоров'я як найбільшої цінності. Ще у 1948 р. Всесвітня організація здоров'я визначила, що здоров'я - це стан повного фізичного, психічного та соціального благополуччя, а не лише відсутність хворіб чи вад [9]. Сьогодні ВООЗ визначає це поняття як особливу силу, яка заснована на фізичних характеристиках людини, і служить для збереження й розвитку біологічних, фізіологічних, психологічних функцій, оптимальної працездатності та соціальної активності при максимальній тривалості активного життя. У XXI сторіччі акценти здорової людини ставляться на здоровому харчуванні, здоровому способі життя (спорт, фізична активність, підтримка тіла у гарному стані), здоровому інформаційному просторі (відсутність негативної інформації як в 3МI, так і серед оточення), гарному соціальному стані (можливість купувати не лише здорову їжу, а також бути забезпеченим усіма потребами по піраміді Маслоу). Все це дозволяє представити здоров'я як особливий товар, який може купити споживач. А через високий попит на цей товар, все більшого значення набуває лікувально-оздоровчий туризм. 
Україна за своїми природно-кліматичними умовами та рекреаційно-оздоровчими ресурсами здавна вважається одною $з$ найперспективніших оздоровниць світу. На іiї території завдяки багатству флори та фауни, наявності рекреаційних місцевостей, м'якому клімату, різноманітності ландшафтів $\epsilon$ можливість розвивати рекреаційну та оздоровчу базу. Але все це можливо лише за наявності сучасної санаторно-курортної бази та активного розвитку санаторно-курортної діяльності.

Структура вітчизняної санаторно-курортної галузі сьогодні представлена різноманітними спеціалізованими закладами та засобами розміщення, які пропонують широкий перелік лікувальних, оздоровчих, рекреаційних та відпочинкових послуг (табл. 1).

Дані табл. 1 свідчать, що об'єкти санаторнокурортної бази за однією сукупністю ознак належать до медицини та охорони здоров'я, за іншою до туристичної діяльності. 3 одного боку, вони $\epsilon$ важливою складовою відновлення трудового потенціалу населення країни, з іншого - стратегічно важливим напрямом поповнення бюджету країни. На сьогодні вітчизняні санаторно-курортні та оздоровчі підприємства підпорядковані двом міністерствам - Міністерству охорони здоров'я (як заклад охорони здоров'я) та Міністерству культури та інформаційної політики (як засіб розміщення), що, власне, й визначає неоднозначність трактування назви цієї сукупності підприємств та їх структури. Внаслідок цього виникли розходження і $з$ понятійним апаратом та методичним інструментарієм у чинних нормативно-правових актах України щодо діяльності суб'єктів господарської діяльності, що працюють у санаторно- курортній сфері. Крім того, варто відзначити ще й проблему належного обліку об'єктів санаторнокурортної бази для реальної оцінки іiі розвитку через неоднозначність статистичної інформації, яка узагальнюється Державною службою статистики України. Поза тим, спробуємо проаналізувати загальні тенденції розвитку вітчизняної санаторно-курортної галузі.

Відповідно до офіційних статистичних даних, сучасна санаторно-курортна база представлена спеціалізованими засобами розміщення, кількість яких на початок 2018 р. становила 1641 од. (без врахування анексованих територій), що становить майже половину від їх кількості у 1995 р. (рис. 1). Тобто, за період незалежності України потужна санаторно-курортна база, яка існувала за радянських часів, практично зруйнована, а в 2014 році до цієї негативної тенденції слід додати ще процеси анексії території Автономної Республіки Крим, де знаходилася значна частка таких засобів розміщення. Основними причинами такої негативної тенденції $\epsilon$, безперечно, зміна форми господарювання санаторно-курортних закладів, зокрема значне зменшення їх державного фінансування i перехід на самофінансування; зменшення рівня платоспроможності одної частини населення та активізація виїзду за межі України з метою відпочинку та оздоровлення на більш якісних зарубіжних курортах - другої його частини тощо.

Звичайно, наведені дані не є цілком актуальними, оскільки інформація за 2017 р. це фактично дані п'ятирічної давності. Проте, на жаль, інша офіційна й неофіційна інформація відсутня. Але враховуючи сьогоднішню ситуацію із світовою пандемією COVID-19 та запровадженням жор-

\section{Узагальнена типологія об'сктів санаторно-курортної бази України}

\begin{tabular}{|c|c|c|}
\hline Об'єкт & Визначення & Документ, який регламентус визначення \\
\hline $\begin{array}{l}\text { Санаторно-курортний заклад: } \\
\text { бальнеологічна лікарня } \\
\text { (у т. ч. дитяча); грязелікарня } \\
\text { (у т. ч. дитяча); дитячий оздоровчий } \\
\text { центр; курортна поліклініка; } \\
\text { міжнародний дитячий медичний } \\
\text { центр; санаторій (у т. ч. дитячий, } \\
\text { однопрофільний, багатопрофільний, } \\
\text { спеціалізований); санаторій для } \\
\text { дітей з батьками; санаторій- } \\
\text { профілакторій }\end{array}$ & $\begin{array}{l}\text { заклад охорони здоров’я, що } \\
\text { розташований на територіях } \\
\text { курортів і забезпечує } \\
\text { подання громадянам } \\
\text { послуг лікувального, } \\
\text { профілактичного та } \\
\text { реабілітаційного характеру } \\
\text { з використанням природних } \\
\text { лікувальних ресурсів }\end{array}$ & $\begin{array}{l}\text { Закон України “Про курорти”, ст. 22; } \\
\text { Наказ Міністерства охорони здоров’я } \\
\text { України від 28.10.2002 № } 385 \text { “Про } \\
\text { затвердження переліків закладів охорони } \\
\text { здоров’я, лікарських, провізорських } \\
\text { посад, посад молодших спеціалістів } \\
\text { з фармацевтичною освітою, посад } \\
\text { професіоналів у галузі охорони здоров’я, } \\
\text { посад фахівців у галузі охорони здоров’я та } \\
\text { посад професіоналів з вищою немедичною } \\
\text { освітою у закладах охорони здоров’я” }\end{array}$ \\
\hline $\begin{array}{l}\text { Засіб розміщення: база відпочинку; } \\
\text { будинок відпочинку; курортний } \\
\text { готель; дитячий табір; пансіонат; } \\
\text { профілакторій; санаторій }\end{array}$ & $\begin{array}{l}\text { засіб розміщення, який } \\
\text { розташований на території } \\
\text { курорту або рекреаційної } \\
\text { зони і забезпечує надання } \\
\text { послуг лікувального, } \\
\text { профілактично-лікувального, } \\
\text { оздоровчо-профілактичного, } \\
\text { оздоровчо-відпочинкового } \\
\text { характеру }\end{array}$ & $\begin{array}{l}\text { Державний стандарт України ДСТУ } \\
\text { 4527:2006 “Послуги туристичні. Засоби } \\
\text { розміщення. Терміни та визначення” }\end{array}$ \\
\hline
\end{tabular}




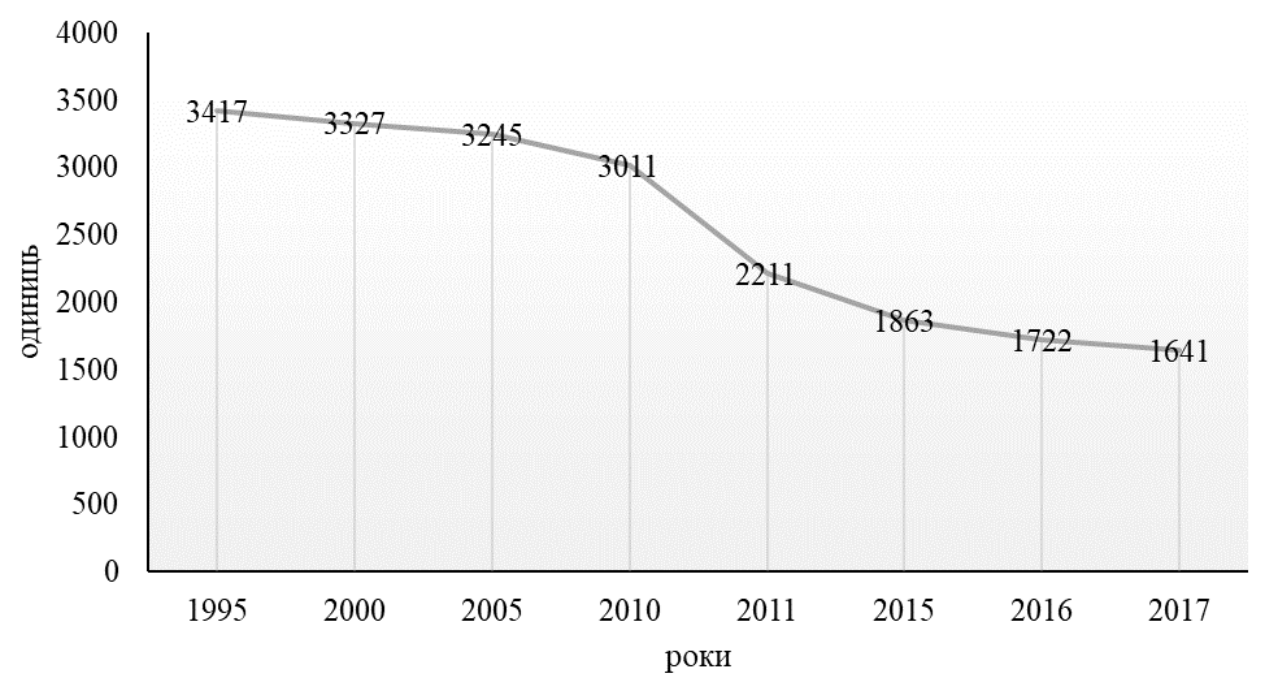

Рис. 1. Динаміка розвитку санаторно-курортних та оздоровчих закладів України [10]

стких карантинних заходів, 3 великою часткою ймовірності можна передбачити подальше зменшення означеного показника. Підтвердженням цього можуть бути дані Національної туристичної організації України, щодо обсягів в’їзих та внутрішніх туристичних потоків 3 метою дозвілля, відпочинку й лікування (табл. 2) та їх частки у загальній кількості, яка за 2011-2019 рр. скоротилися $з$ 79,6\% до 66,2\%, а в кількісному вимірі обсяг таких туристів за означений період скоротився майже на $18 \%$ (рис. 2).

Тенденція щодо виїзних туристичних потоків 3 метою дозвілля, відпочинку й лікування є протилежною. Їх обсяги зросли в 2,5 рази, а частка становить майже 94\%. Проте, ці дані, на нашу думку, більшою мірою відображають сучасні тенденції нелегальної трудової міграції, коли громадяни України, користуючись безвізовим режимом перебування на території країн Європейського Союзу, працевлаштовуються на дозволений термін без офіційного працевлаштування.

Як зазначалося вище у табл. 1 для надання санаторно-курортних та лікувальних послуг в Україні функціонують різні типи спеціалізованих закладів та засобів розміщення. Нажаль, офіційна статистика однозначно не відображає загального їх переліку. Зокрема, у різних інформаційних виданнях публікуються суперечливі узагальнені дані (табл. 3). Така вихідна інформаційна база значно утруднює об'єктивний аналіз тенденцій розвитку санаторно-курортної бази України.

Як свідчать дані табл. 3 найбільшу частку в структурі об'єктів санаторно-курортної галузі України за даними офіційної статистики займають бази відпочинку та санаторії. На нашу думку, такі цифри не відображають реального стану речей, адже у такому розподілі не враховано величезний сегмент колективних засобів розміщення типу Resort\&SPA, які доволі активно розвиваються в Україні, враховуючи їх присутність на різних сайтах он-лайн бронювання. Зокрема, на сайті booking.com представлено 45 помешкань, серед яких Radisson Blu Resort Bukovel, Mirotel Resort and Spa, Гранд Адмірал Резорт енд СПА, Voevodyno Resort, Superior Golf and SPA Resort та багато інших. Також в Україні почали з'являтися i медичні готелі, яскравим прикладом яких є Edem Resort Medical \& SPA, розташований неподалік м. Львова. Крім того, до структури санаторнокурортних об'єктів варто включити індивідуальній сектор розміщення, який пропонує не тільки різноманітні помешкання, а й відповідні послуги оздоровчого, відновлюючого та відпочинкового характеру, використовуючи при цьому природно-кліматичні умови та рекреаційно-оздоровчі ресурси.

Динаміка туристичних потоків в Україні [10; 11]

\begin{tabular}{|l|c|c|c|c|c|}
\hline \multicolumn{1}{|c|}{ Туристичні потоки } & \multicolumn{3}{c|}{ Роки, тис. осіб } & $\mathbf{2 0 1 9}$ р. у \% \\
\cline { 2 - 6 } & $\mathbf{2 0 1 1}$ & $\mathbf{2 0 1 5}$ & $\mathbf{2 0 1 7}$ & $\mathbf{2 0 1 9}$ & $\mathbf{2 0 1 1}$ p. \\
\hline Всього & 1840,48 & 2019,58 & 2806,4 & 6132,10 & 333,18 \\
\hline у т. ч. з метою дозвілля, відпочинку та лікування & 1690,17 & 1739,38 & 2596,40 & 5827,60 & 344,79 \\
\hline Всього в’їзні та внутрішні потоки & 609,68 & 372,19 & 516,57 & 607,23 & 99,60 \\
\hline $\begin{array}{l}\text { у т. ч. в'їзні та внутрішні потоки з метою дозвілля, } \\
\text { відпочинку та лікування }\end{array}$ & 485,41 & 248,06 & 371,85 & 401,74 & 82,76 \\
\hline
\end{tabular}




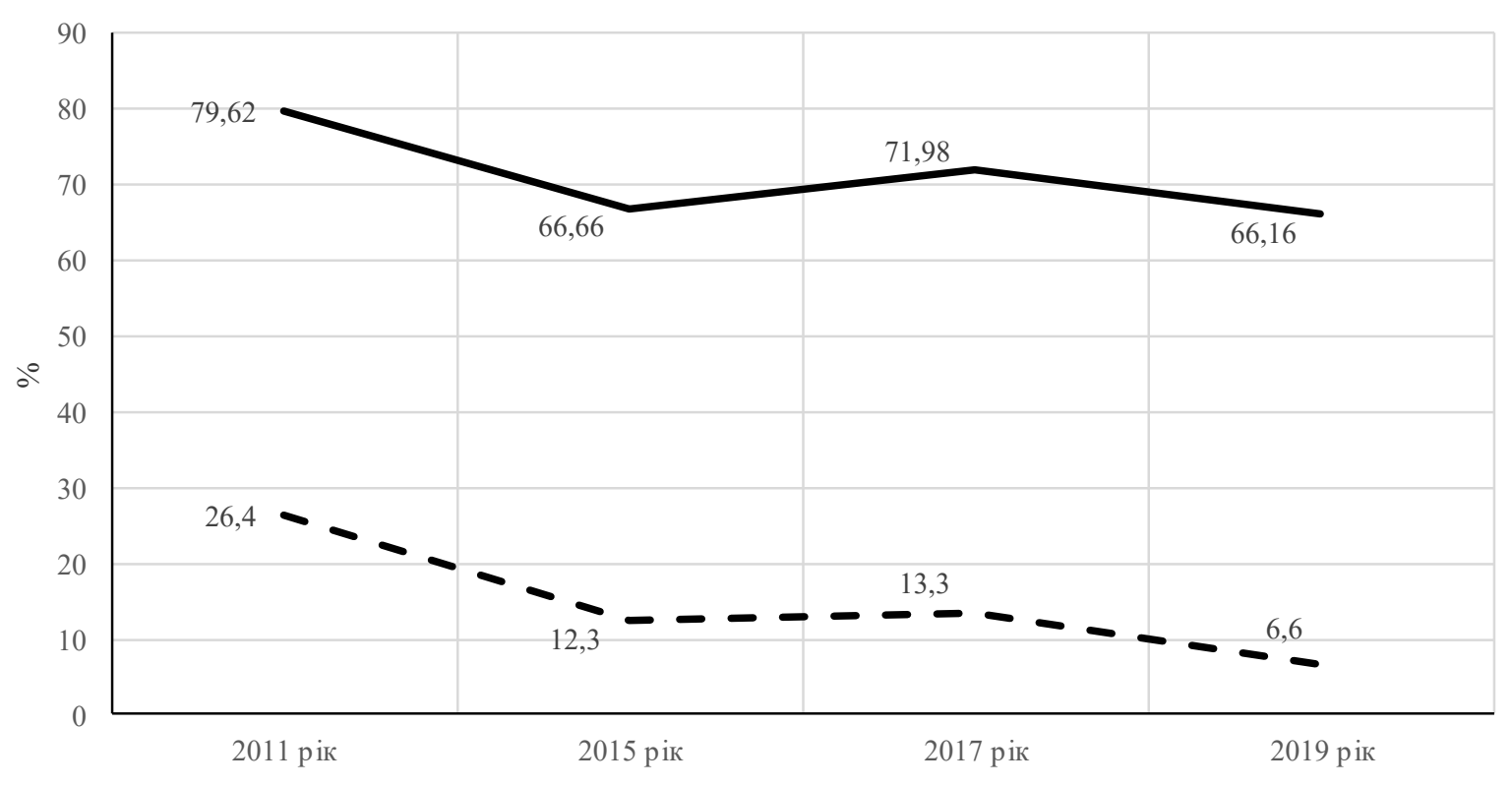

- - Частка в'їзних та внутрішніш потоків з метою дозвілля, відпочинку та лікування у загальній кількості туристичних потоків

Частка в'їзних та внутрішніх потоків з метою дозвілля, відпочинку та лікування у загальній кількості туристичних потоків $з$ такою метою

Рис. 2. Динаміка структури туристичних потоків

3 метою дозвілля, відпочинку та лікування в Україні [10; 11]

Ще одним аспектом розвитку вітчизняної санаторно-курортної бази є іiї територіальний розподіл. Загалом, спеціалізовані засоби розміщення нерівномірно розташовані на території України, що є логічним в силу наявності відповідних природно-кліматичних ресурсів. На сьогодні, найбільша їх кількість локалізуються у Дніпропетровській, Запорізькій, Львівській, Миколаївській, Одеській та Херсонській областях (табл. 4). Загалом, географія санаторнокурортних закладів України значною мірою відпо- відає територіально-компонентній структурі рекреаційних ресурсів і рекреаційних потреб.

Незважаючи на негативні тенденції до скорочення об'єктів санаторно-курортної галузі, Україна має достатню кількість курортів різної спеціалізації 3 відповідними санаторно-курортними ресурсами. Але для активного розвитку цієї галузі українським курортам необхідно вирішити ряд проблем, пов'язаних із фінансуванням, управлінням та модернізацією. У першу чергу, сучасні

Структура об'єктів санаторно-курортної галузі України у 2017 р. [10]

Таблиця 3

\begin{tabular}{|c|c|c|c|}
\hline \multicolumn{2}{|c|}{ Спеціалізовані засоби розміщування } & \multicolumn{2}{|c|}{ Санаторно-курортні та оздоровчі заклади } \\
\hline засіб розміщення & кількість, од. & заклад & кількість, од. \\
\hline санаторії & 169 & $\begin{array}{l}\text { санаторії та пансіонати } \\
3 \text { лікуванням }\end{array}$ & 284 \\
\hline дитячі санаторії & 103 & санаторії-профілакторії & 55 \\
\hline пансіонати з лікуванням & 12 & будинки і пансіонати відпочинку & 67 \\
\hline $\begin{array}{l}\text { дитячі заклади оздоровлення цілорічної дії, } \\
\text { дитячі центри }\end{array}$ & 14 & бази та інші заклади відпочинку & 1235 \\
\hline санаторії-профілакторії & 55 & $\begin{array}{l}\text { дитячі заклади оздоровлення } \\
\text { та відпочину }\end{array}$ & 9745 \\
\hline $\begin{array}{l}\text { бальнеологічні лікарні, грязелікарні, } \\
\text { бальнеогрязелікарні (включаючи дитячі) }\end{array}$ & 3 & Разом & 11386 \\
\hline будинки відпочинку & 14 & & \\
\hline пансіонати відпочинку & 53 & & \\
\hline $\begin{array}{l}\text { бази відпочинку, інші заклади відпочинку } \\
\text { (крім турбаз) }\end{array}$ & 1212 & & \\
\hline оздоровчі заклади 1-2 денного перебування & 6 & & \\
\hline Разом & 1641 & & \\
\hline
\end{tabular}


Таблиця 4

Динаміка розвитку спеціалізованих засобів розміщення у розрізі регіонів України [10]

\begin{tabular}{|c|c|c|c|c|c|c|c|c|}
\hline \multirow{2}{*}{ Область } & \multicolumn{7}{|c|}{ Роки, \% до загальної кількості } & \multirow{2}{*}{$\begin{array}{c}\text { +/- в.I. 3a } \\
\text { 2011-2017 pp. }\end{array}$} \\
\hline & 2011 & 2012 & 2013 & 2014 & 2015 & 2016 & 2017 & \\
\hline Дніпропетровська & 6,1 & 5,5 & 5,4 & 6,2 & 6,1 & 6,7 & 6,6 & $+0,5$ \\
\hline Запорізька & 8,9 & 9,5 & 9,9 & 11,9 & 12,1 & 15,2 & 14,8 & $+5,9$ \\
\hline Львівська & 4,0 & 3,3 & 3,0 & 3,5 & 3,1 & 3,3 & 3,7 & $-0,3$ \\
\hline Миколаївська & 9,6 & 9,2 & 9,5 & 11,7 & 11,9 & 10,9 & 11,7 & $+2,1$ \\
\hline Одеська & 12,7 & 17,2 & 18,4 & 20,4 & 21,3 & 20,4 & 19,6 & $+6,9$ \\
\hline Херсонська & 8,2 & 9,8 & 10,5 & 10,9 & 10,1 & 8,6 & 10,2 & $+2,0$ \\
\hline
\end{tabular}

стратегії розвитку курортів повинні передбачити заходи зі створення системи заохочення інвестицій у модернізацію та будівництво закладів санаторнокурортної галузі, створення доступного за ціною оздоровчого продукту, дотримання державних стандартних методик у галузі лікування та медичної реабілітації на курортах тощо. У перспективі діяльність державних органів влади та об'єднаних територіальних громад повинна бути спрямована на створення інноваційних центрів здоров'я у вигляді так званих рекропарків, рекрополісів, курортополісів і рекреаційних зон у традиційних курортних регіонах (Карпати, Полісся, узбережжя Азовського і Чорного морів), що дозволить сформувати загальнонаціональну оздоровчу мережу, інтегровану в міжнародну світову спільноту.

Висновки 3 цього дослідження i перспективи подальших розвідок у даному напрямку. Лікувально-оздоровчий туризм набуває все більшого значення серед інших видів відпочинку. В Україні для його розвитку існують головні передумови, пов'язані 3 наявністю багатих та різноманітних природних ресурсів (гористий рельєф, морське узбережжя, м'який клімат, велика кількість мінеральних та термальних джерел). Сучасний стан санаторно-курортної галузі України в кількісному вимірі має стійку тенденцію до скорочення іiі матеріально-технічної бази, що суперечить тенденції зростання інтересу населення до оздоровлення та покращення свого здоров'я. Крім того, різноманітні дослідження свідчать ще й про недостатній рівень якості санаторно-курортних послуг, які надаються спеціалізованими закладами, що ще більшою мірою загострює проблеми розвитку галузі. Ці проблеми, насамперед, спричинені відсутністю ефективної комплексної системи управління санаторно-курортним комплексом. За таких умов, для активізації розвитку закладів санаторно-курортного та оздоровчого профілю доцільною є реалізація заходів:

1) створення умов для інвестиційної діяльності як вітчизняних, так і закордонних інвесторів з метою модернізації існуючої і розвитку нової матеріальнотехнічної бази санаторно-курортного комплексу;

2) налагодження конструктивного та ефективного державно-приватного партнерства 3 метою комплексного раціонального використання природно-рекреаційних ресурсів та санаторнокурортних об'єктів;

3) відновлення дієвого механізму соціального захисту населення в частині державного фінансування санаторно-курортних путівок конкретним споживачам;

4) розробка системи матеріального стимулювання у формі пільгового оподаткування санаторно-курортних та оздоровчих закладів 3 метою підвищення їх підприємницької діяльності;

5) популяризація та впровадження європейських стандартів обслуговування та надання санаторно-курортних й оздоровчих послуг;

3 огляду на те, що Україна має один із найкращих природних лікувально-оздоровчих потенціалів у Європі, питання вдосконалення санаторно-курортного комплексу стає одним iз найпріоритетніших напрямів розвитку туризму, що приводить до поповнення бюджету і зміцнення державної економіки в цілому. Тому подальші дослідження необхідно пов'язати з розробкою та обгрунтуванням системи заходів сприяння розвитку цього виду туризму в Україні.

\section{Список використаних джерел:}

1.Жидяк О. Р., Вівчарук О. М., Фурсіна О. В. Тенденції розвитку санаторно-курортного комплексу: напрями змін та фактори впливу. Соціально-економічні проблеми сучасного періоду України. 2018. № 5. С. 3-6.

2.Ковач М. Й. Інноваційний розвиток санаторно-курортного господарства регіону: проблеми і ризики. Економіка та держава. 2013. № 6. С. 43-45.

3. Литовченко І. Л., Семенов В. Ф. Фактори конкурентоспроможності рекреаційних підприємств на ринку послуг. Науковий вісник Буковинського державного фінансово-економічного університету. Економічні науки. 2015. Вип. 1(28). Ч. 2. С. 102-105.

4. Мигалина Ю. Ю. Санаторно-курортні заклади України: бізнес чи соціальна спрямованість? Економіст. 2011. № 6. C. 38-40. 
5.Нездойминов С. Г. Современные тенденции развития лечебно-оздоровительного туризма в Украине. Туризм: право и экономика. 2014. № 2. С. 20-24.

6.Забалдіна Ю. Б. Економічна діагностика та прогнозування розвитку регіонального ринку туристичних послуг : автореф. дис. ... канд. екон. наук : 08.10.01. Київ, 2006. 20 с.

7. Охріменко А. Г. Удосконалення територіальної організації рекреаційного комплексу Подільського регіону : автореф. дис. ... канд. екон. наук : 08.10.01. Київ, 2010. 18 с.

8. Федоров І. О. Оцінка ефективності фінансово-господарської діяльності підприємств санаторно-курортного комплексу : автореф. дис. ... канд. екон. наук : 08.040.01. Суми, 2016. 19 с.

9. Преамбула до Конституції Всесвітньої організації охорони здоров’я, затверджена на Міжнародній конференції з питань охорони здоров’я, Нью-Йорк, 19-22 червня 1946 р.; підписана 22 липня 1946 р. представниками 61 країни (Архівні документи Всесвітньої організації охорони здоров’я, № 2, стор. 100), введена в дію 07 квітня 1948 p. URL: https://apps.who.int/gb/r/index.html

10. Державна служба статистики України : офіційний веб-сайт. URL: http://www.ukrstat.gov.ua/

11. Національна туристична організація України : офіційний веб-сайт. URL: http://www.ntoukraine.org/assets/ files/ntou-barometer-2020.pdf

\section{References:}

1.Zhydiak O. R., Vivcharuk O. M., Fursina O. V. (2018) Tendentsii rozvytku sanatorno-kurortnoho kompleksu: napriamy zmin ta faktory vplyvu [Trends in the development of the sanatorium-resort complex: directions of change and factors of influence]. Sotsialno-ekonomichni problemy suchasnoho periodu Ukrainy, no. 5, pp. 3-6. (in Ukrainian)

2. Kovach M. Y. (2013). Innovatsiinyi rozvytok sanatorno-kurortnoho hospodarstva rehionu: problemy i ryzyky [Innovative development of sanatorium and resort economy of the region: problems and risks]. Ekonomika ta derzhava, no. 6, pp. 43-45. (in Ukrainian)

3. Lytovchenko I. L., Semenov V. F. (2015). Faktory konkurentospromozhnosti rekreatsiinykh pidpryiemstv na rynku posluh [Factors of competitiveness of recreational enterprises in the market of services]. Naukovyi visnyk Bukovynskoho derzhavnoho finansovo-ekonomichnoho universytetu. Ekonomichni nauky, vol. 1(28), ch. 2, pp. 102-105. (in Ukrainian)

4. Myhalyna Yu. Yu. (2011). Sanatorno-kurortni zaklady Ukrainy: biznes chy sotsialna spriamovanist? [Sanatoriums of Ukraine: business or social orientation?] Ekonomist. no. 6. S. 38-40. (in Ukrainian)

5. Nezdoimynov S. H. (2014) Sovremennye tendentsyy razvytyia lechebno-ozdorovytelnoho turyzma v Ukrayne [Current trends in the development of health tourism in Ukraine]. Turyzm: pravo y ekonomyka, no. 2, pp. 20-24. (in Rassian)

6.Zabaldina Yu. B. (2006) Ekonomichna diahnostyka ta prohnozuvannia rozvytku rehionalnoho rynku turystychnykh posluh [Economic diagnostics and forecasting of the development of the regional market of tourist services]: avtoref. dys. ... kand. ekon. nauk: 08.10.01. Kyiv, 20 p. (in Ukrainian)

7. Okhrimenko A. H. (2010) Udoskonalennia terytorialnoi orhanizatsii rekreatsiinoho kompleksu Podilskoho rehionu [Improving the territorial organization of the recreational complex of the Podolsk region]: avtoref. dys. ... kand. ekon. nauk: 08.10.01. Kyiv, 18 p. (in Ukrainian)

8. Fedorov I. O. (2016) Otsinka efektyvnosti finansovo-hospodarskoi diialnosti pidpryiemstv sanatorno-kurortnoho kompleksu [Estimation of efficiency of financial and economic activity of the enterprises of a sanatorium complex]: avtoref. dys. ... kand. ekon. nauk: 08.040.01. Sumy, 19 p. (in Ukrainian)

9. Preambula do Konstytutsii Vsesvitnoi orhanizatsii okhorony zdorovia [Preamble to the Constitution of the World Health Organization], zatverdzhena na Mizhnarodnii konferentsii z pytan okhorony zdorovia, Niu-York, 19-22 chervnia 1946 r; pidpysana 22 lypnia 1946 r. predstavnykamy 61 krainy (Arkhivni dokumenty Vsesvitnoi orhanizatsii okhorony zdorovia, № 2, stor. 100), vvedena v diiu 07 kvitnia 1948 r. Retrieved from: https://apps.who.int/gb/r/index.html (in English)

10.Derzhavna sluzhba statystyky Ukrainy [State Statistics Service of Ukraine]: ofitsiinyi sait. Retrieved from: http://www.ukrstat.gov.ua/ (in Ukrainian)

11. Natsionalna turystychna orhanizatsiia Ukrainy [National Tourist Organization of Ukraine]: ofitsiinyi veb-sait. Retrieved from: http://www.ntoukraine.org/assets/files/ntou-barometer-2020.pdf (in Ukrainian) 